\title{
Radiation dosimetry and
}

\section{biodistribution of 11C-ABP688}

measured in healthy volunteers

\section{Journal Article}

\section{Author(s):}

Treyer, Valerie; Streffer, Johannes; Ametamey, Simon M.; Bettio, Andrea; Bläuenstein, Peter; Schmidt, Mark; Gasparini, Fabrizio; Fischer, Uta; Hock, Christoph; Buck, Alfred

\section{Publication date:}

2008-04-01

\section{Permanent link:}

https://doi.org/10.3929/ethz-b-000082930

Rights / license:

In Copyright - Non-Commercial Use Permitted

\section{Originally published in:}

European Journal of Nuclear Medicine and Molecular Imaging 35(4), https://doi.org/10.1007/s00259-007-0638-4 


\title{
Radiation dosimetry and biodistribution of 11C-ABP688 measured in healthy volunteers
}

\author{
Valerie Treyer • Johannes Streffer • \\ Simon M. Ametamey • Andrea Bettio • \\ Peter Bläuenstein • Mark Schmidt • \\ Fabrizio Gasparini • Uta Fischer • \\ Christoph Hock • Alfred Buck
}

Received: 16 March 2007 / Accepted: 9 October 2007 /Published online: 11 December 2007

(C) Springer-Verlag 2007

\begin{abstract}
Introduction In this study, we assessed the whole-body biodistribution and radiation dosimetry of the new glutamatergic ligand ${ }^{11} \mathrm{C}-\mathrm{ABP} 688$. This ligand binds specifically to the metabotropic glutamatergic receptor of subtype 5 (mGluR5).

Materials and methods The study included five healthy male volunteers aged 20-29 years. After intravenous injection of 240-260 MBq, a series of four to ten whole-body positron emission tomography/computed tomography scans were initiated, yielding 60-80 min of data. Residence times were then calculated in the relevant organs, and the software packages Mirdose and Olinda were used to calculate the absorbed radiation dose and the effective dose equivalent.
\end{abstract}

V. Treyer $\cdot$ A. Buck $(\bowtie)$

PET Center, Division of Nuclear Medicine,

University Hospital Zurich,

Rämistrasse 100,

8091 Zurich, Switzerland

e-mail: fred.buck@usz.ch

J. Streffer • U. Fischer $\cdot$ C. Hock

Division of Psychiatry Research, University of Zurich,

Zurich, Switzerland

S. M. Ametamey $\cdot$ A. Bettio $\cdot$ P. Bläuenstein

Department of Chemistry and Applied Biosciences of ETH,

Center for Radiopharmaceutical Science of ETH, PSI and USZ,

Zurich, Switzerland

M. Schmidt

Novartis Pharma AG,

Basel, Switzerland

F. Gasparini

Novartis Institutes for Biomedical Research,

Basel, Switzerland
Results Of the excreted ${ }^{11} \mathrm{C}$ activity at 1 hour, approximately $80 \%$ were eliminated via the hepato-biliary pathway and $20 \%$ through the urinary tract. The absorbed dose (mGy/ $\mathrm{MBq})$ was highest in the liver (1.64 E -2 $\pm 5.08 \mathrm{E}-3)$, gallbladder (8.13 E $-3 \pm 5.6 \mathrm{E}-3$ ), and kidneys (7.27 E $-3 \pm$ $2.79 \mathrm{E}-3)$. The effective dose equivalent was $3.68 \pm$ 0.84 microSv/MBq. Brain uptake in the areas with high mGluR5 density was 2-3 (SUV). The agreement between the values obtained from Mirdose and the Olinda was excellent. Conclusion ${ }^{11} \mathrm{C}$-ABP688 is a very promising ligand for the investigation of mGluR5 receptors in humans. Brain uptake is high and the effective dose equivalent so low that serial examinations in the same subject seem feasible.

Keywords ${ }^{11} \mathrm{C}$-ABP688 Metabotropic glutamate receptor subtype $5 \cdot$ Whole-body PET/CT . Dosimetry

\section{Introduction}

Since the cloning of the first metabotropic glutamate receptor (mGlu1) in 1991 [1], seven additional subtypes of this receptor (mGlu2-8) have been cloned. For the mGluR5 receptor subtype, based on the wide and consistent effects of selective noncompetitive allosteric antagonists such as 2-methyl-6-(phenylethynyl)pyridine in animal models for anxiety [2,3], it has been hypothesized that this receptor could be a valuable target for the treatment of anxiety-related disorders [4-6]. The development of positron emission tomography (PET) tracers for the glutamatergic receptors proved difficult. Only recently, a series of PET ligands, allowing the in vivo imaging in rhesus monkeys, has been described [7]. Recently, we identified ${ }^{11}$ C-ABP688 (3-(6-methyl-pyridin-2-ylethynyl)-cyclohex- 


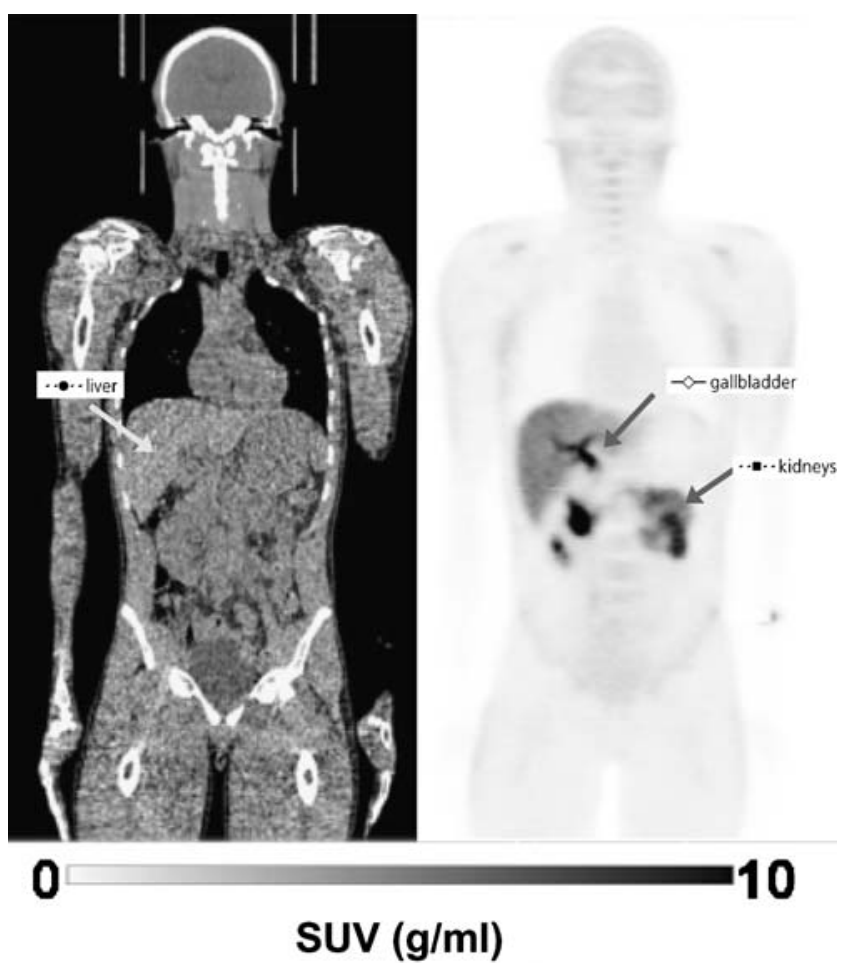

Fig. 1. Whole-body $\mathrm{CT}$ and PET $60-70 \mathrm{~min}$ after injection of $260 \mathrm{MBq}{ }^{11} \mathrm{C}-\mathrm{ABP} 688$

2-enone- $O-\left[{ }^{11} \mathrm{C}\right]$-methyl-oxime) as a very promising ligand to investigate mGluR5 [8]. This compound is a highly selective allosteric antagonist of the mGluR5 receptor in vitro, and initial studies have demonstrated a high selectivity for mGluR5 receptors in vivo [8]. The purpose of this study was to evaluate the whole-body biodistribution and radiation dosimetry of ${ }^{11} \mathrm{C}-\mathrm{ABP} 688$ in humans using whole-body PET/computed tomography (CT).

\section{Materials and methods}

Synthesis of ${ }^{11} \mathrm{C}-\mathrm{ABP} 688$

The synthesis of ${ }^{11} \mathrm{C}-\mathrm{ABP} 688$ has been described in detail elsewhere [8]. Briefly, desmethyl ABP688 was reacted with ${ }^{11} \mathrm{C}$-methyl iodide produced from the GE PET trace system at $90^{\circ} \mathrm{C}$ for $5 \mathrm{~min}$. The product was purified by semipreparative high-performance liquid chromatography using a reversed-phase column. Formulation of ${ }^{11} \mathrm{C}-\mathrm{ABP} 688$ for in vivo administration was accomplished using $0.15 \mathrm{M}$ phosphate buffer and ethanol. The average specific activity was $232 \mathrm{GBq} / \mu \mathrm{mol}(\mathrm{SD} \pm 72.56)$.

\section{Subjects}

The study included five healthy male subjects, aged $24.5 \pm$ 3.2 (range, 20-29 years). All subjects gave their written informed consent, and the study was approved by the local ethics committee for radiological research in Zurich.

Positron emission tomography

The subjects were positioned supine in the PET/CT scanner (Discovery LS and Discovery RX, GE Healthcare, Milwaukee). To correct for photon attenuation and for anatomical reference, a low dose CT scan was performed before tracer administration. After the injection of 240 $260 \mathrm{MBq}{ }^{11} \mathrm{C}$-ABP688, a series of four to ten whole-body scans was initiated. Each scan covered the body from the head to the knees and consisted of several bed positions (15 cm field of view). In each bed position, data were acquired for $1-2 \mathrm{~min}$ in $2 \mathrm{D}$ mode. Total acquisition time was $60-80 \mathrm{~min}$. The data were then reconstructed on a $128 \times 128$ matrix (slice thickness, $4.25 \mathrm{~mm}$ ) and corrected for photon attenuation using the CT scan. Volumes of interest were placed over different organs using the software PMOD (http://www.pmod.com) and the CT scan for anatomical reference, and the time course of radioactivity $(\mathrm{Bq} / \mathrm{ml})$ was calculated. Because the output from the commercial reconstruction software was a decay-corrected whole-body data set and dosimetry requires the actual, nondecay-corrected time-course of organ radioactivity, the decay correction was removed from each time-activity curve, considering also the actual acquisition time of each field of view.

\section{Dosimetry}

The calculation of dosimetry requires the area under the time-activity curves, which was calculated as follows: If possible, a declining monoexponential was fitted to the data and extrapolated to time-point zero and infinity. If monoexponential fitting was not appropriate, the actual data were numerically integrated to the end point of the scan. After this time, it was assumed that the activity dropped with the

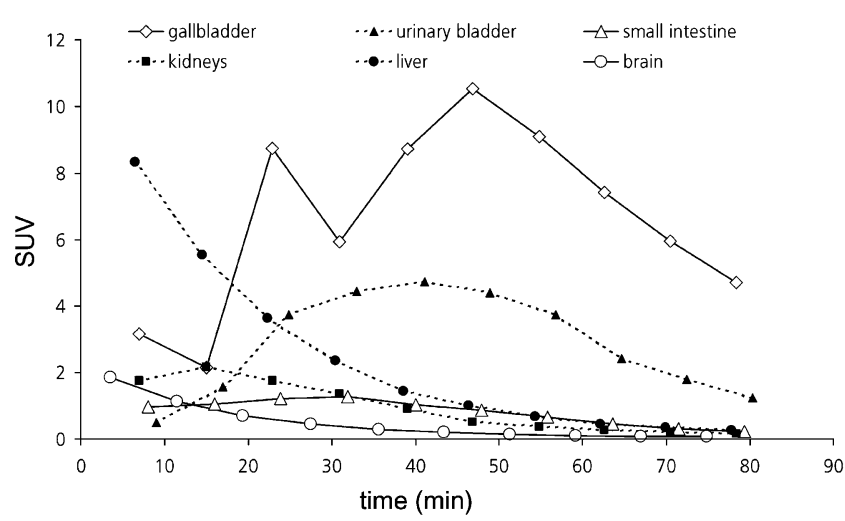

Fig. 2. Typical tissue time-activity curves of non-decay-corrected ${ }^{11} \mathrm{C}$ activity 
Table 1. Residence times (hours) of 11C-ABP688

\begin{tabular}{|c|c|c|c|c|c|c|c|}
\hline & Subject 1 & Subject 2 & Subject 3 & Subject 4 & Subject 5 & Mean & $\mathrm{SD}$ \\
\hline Muscles & $1.314 \mathrm{E}-01$ & $9.165 \mathrm{E}-02$ & $1.317 \mathrm{E}-01$ & $1.276 \mathrm{E}-01$ & $1.157 \mathrm{E}-01$ & $1.196 \mathrm{E}-01$ & $1.692 \mathrm{E}-02$ \\
\hline Liver & $1.434 \mathrm{E}-01$ & $6.047 \mathrm{E}-02$ & $8.975 \mathrm{E}-02$ & $8.431 \mathrm{E}-02$ & $9.687 \mathrm{E}-02$ & $9.496 \mathrm{E}-02$ & $3.034 \mathrm{E}-02$ \\
\hline Bone marrow & $2.404 \mathrm{E}-02$ & $1.514 \mathrm{E}-02$ & $1.547 \mathrm{E}-02$ & $1.634 \mathrm{E}-02$ & $1.759 \mathrm{E}-02$ & $1.772 \mathrm{E}-02$ & $3.661 \mathrm{E}-03$ \\
\hline Small intestine & $2.067 \mathrm{E}-02$ & $1.467 \mathrm{E}-02$ & $1.689 \mathrm{E}-02$ & $1.907 \mathrm{E}-02$ & $1.504 \mathrm{E}-02$ & $1.727 \mathrm{E}-02$ & $2.582 \mathrm{E}-03$ \\
\hline Brain & $1.845 \mathrm{E}-02$ & $1.293 \mathrm{E}-02$ & $1.679 \mathrm{E}-02$ & $1.591 \mathrm{E}-02$ & $1.259 \mathrm{E}-02$ & $1.533 \mathrm{E}-02$ & $2.524 \mathrm{E}-03$ \\
\hline Kidney & $1.043 \mathrm{E}-02$ & $4.181 \mathrm{E}-03$ & $6.838 \mathrm{E}-03$ & $3.693 \mathrm{E}-03$ & $8.490 \mathrm{E}-03$ & $6.726 \mathrm{E}-03$ & $2.851 \mathrm{E}-03$ \\
\hline Urinary bladder & $8.220 \mathrm{E}-03$ & $1.676 \mathrm{E}-03$ & $5.244 \mathrm{E}-03$ & $3.364 \mathrm{E}-03$ & $8.135 \mathrm{E}-03$ & $5.328 \mathrm{E}-03$ & 2.892E-03 \\
\hline Lung & $2.796 \mathrm{E}-03$ & $2.235 \mathrm{E}-03$ & $2.829 \mathrm{E}-03$ & $2.363 \mathrm{E}-03$ & $2.925 \mathrm{E}-03$ & $2.630 \mathrm{E}-03$ & 3.089E-04 \\
\hline Gallbladder & $5.118 \mathrm{E}-04$ & $1.633 \mathrm{E}-03$ & $3.241 \mathrm{E}-03$ & $7.038 \mathrm{E}-05$ & $6.041 \mathrm{E}-03$ & $2.299 \mathrm{E}-03$ & $2.423 \mathrm{E}-03$ \\
\hline Heartwall & $2.283 \mathrm{E}-03$ & $1.588 \mathrm{E}-03$ & $2.055 \mathrm{E}-03$ & $1.959 \mathrm{E}-03$ & $1.826 \mathrm{E}-03$ & $1.942 \mathrm{E}-03$ & $2.590 \mathrm{E}-04$ \\
\hline Pancreas & $1.414 \mathrm{E}-03$ & $5.517 \mathrm{E}-04$ & 1.199E-03 & $1.243 \mathrm{E}-03$ & $1.611 \mathrm{E}-03$ & $1.204 \mathrm{E}-03$ & $3.990 \mathrm{E}-04$ \\
\hline Spleen & $1.335 \mathrm{E}-03$ & $6.712 \mathrm{E}-04$ & $1.320 \mathrm{E}-03$ & $9.744 \mathrm{E}-04$ & $1.155 \mathrm{E}-03$ & $1.091 \mathrm{E}-03$ & 2.765E-04 \\
\hline Testes & $2.120 \mathrm{E}-04$ & $1.825 \mathrm{E}-04$ & $2.381 \mathrm{E}-04$ & $1.360 \mathrm{E}-04$ & $2.057 \mathrm{E}-04$ & $1.948 \mathrm{E}-04$ & 3.839E-05 \\
\hline Thyroid & $1.873 \mathrm{E}-04$ & $1.100 \mathrm{E}-04$ & $1.210 \mathrm{E}-04$ & $1.426 \mathrm{E}-04$ & $1.301 \mathrm{E}-04$ & $1.382 \mathrm{E}-04$ & 2.994E-05 \\
\hline
\end{tabular}

physical half-time of ${ }^{11} \mathrm{C}$. As this assumption neglects clearance of residual activity from the organ, the effective radiation dose will be somewhat overestimated. The residence time in the different organs was calculated by dividing the time integrals by the injected amount of activity. The mean absorbed dose was subsequently calculated using the software Mirdose3 [9] and Windows 98 and for comparison with the software Olinda [10] and Windows 2000.

It is essential to use Mirdose3 with Windows 98 or 95. The combination of Mirdose 3 and Windows XP yields much lower doses because the $S$ value table is not read correctly. It shows that only the self-absorption doses (identical source and target organ) are considered while all other $\mathrm{S}$ values (target organ different from source organs) are zero.

\section{Results}

Coronal sections of a typical whole-body PET are demonstrated in Fig. 1. Most of the ${ }^{11} \mathrm{C}$ activity is found in the gallbladder and in the bile secreted in the small intestine. The figure illustrates the primarily hepatobiliary excretion of the ${ }^{11} \mathrm{C}$ activity. An illustrative set of tissue time-activity curves is depicted in Fig. 2. In the liver, kidneys, and brain, the clearance of activity after the initial increase was

Table 2. Absorbed dose estimates (mGy/MBq) and effective dose equivalent (mSv/MBq) for 11C-ABP688

\begin{tabular}{|c|c|c|c|c|c|c|c|c|c|}
\hline & Subject 1 & Subject 2 & Subject 3 & Subject 4 & Subject 5 & Mean MIRD & SD MIRD & Mean Olinda & SD Olinda \\
\hline Liver & $2.44 \mathrm{E}-02$ & $1.05 \mathrm{E}-02$ & $1.56 \mathrm{E}-02$ & $1.45 \mathrm{E}-02$ & $1.68 \mathrm{E}-02$ & $1.64 \mathrm{E}-02$ & $5.08 \mathrm{E}-03$ & $1.64 \mathrm{E}-02$ & $5.12 \mathrm{E}-03$ \\
\hline Gallbladder wall & $5.17 \mathrm{E}-03$ & $5.61 \mathrm{E}-03$ & $1.02 \mathrm{E}-02$ & $2.75 \mathrm{E}-03$ & $1.69 \mathrm{E}-02$ & $8.13 \mathrm{E}-03$ & $5.60 \mathrm{E}-03$ & $8.12 \mathrm{E}-03$ & $5.55 \mathrm{E}-03$ \\
\hline Kidneys & $1.10 \mathrm{E}-02$ & 4.64E-03 & 7.32E-03 & $4.50 \mathrm{E}-03$ & 8.87E-03 & $7.27 \mathrm{E}-03$ & $2.79 \mathrm{E}-03$ & $7.27 \mathrm{E}-03$ & $2.79 \mathrm{E}-03$ \\
\hline Small intestine & $7.20 \mathrm{E}-03$ & 4.94E-03 & $5.86 \mathrm{E}-03$ & $6.40 \mathrm{E}-03$ & $5.34 \mathrm{E}-03$ & $5.95 \mathrm{E}-03$ & $8.90 \mathrm{E}-04$ & $5.94 \mathrm{E}-03$ & 8.87E-04 \\
\hline Pancreas & $5.90 \mathrm{E}-03$ & $2.58 \mathrm{E}-03$ & $4.82 \mathrm{E}-03$ & 4.77E-03 & $6.01 \mathrm{E}-03$ & $4.82 \mathrm{E}-03$ & $1.38 \mathrm{E}-03$ & $4.85 \mathrm{E}-03$ & $1.39 \mathrm{E}-03$ \\
\hline Urinary bladder wall & $6.26 \mathrm{E}-03$ & $6.08 \mathrm{E}-03$ & $4.18 \mathrm{E}-03$ & $2.93 \mathrm{E}-03$ & $6.09 \mathrm{E}-03$ & $5.11 \mathrm{E}-03$ & $1.49 \mathrm{E}-03$ & $4.23 \mathrm{E}-03$ & $2.01 \mathrm{E}-03$ \\
\hline Brain & 4.33E-03 & $3.05 \mathrm{E}-03$ & $3.95 \mathrm{E}-03$ & $3.74 \mathrm{E}-03$ & $2.99 \mathrm{E}-03$ & $3.61 \mathrm{E}-03$ & $5.81 \mathrm{E}-04$ & $3.62 \mathrm{E}-03$ & $5.90 \mathrm{E}-04$ \\
\hline Red marrow & $3.46 \mathrm{E}-03$ & $2.12 \mathrm{E}-03$ & $2.40 \mathrm{E}-03$ & $2.44 \mathrm{E}-03$ & $2.60 \mathrm{E}-03$ & $2.60 \mathrm{E}-03$ & $5.09 \mathrm{E}-04$ & $2.61 \mathrm{E}-03$ & $5.14 \mathrm{E}-04$ \\
\hline Heart wall & $3.17 \mathrm{E}-03$ & $2.00 \mathrm{E}-03$ & $2.67 \mathrm{E}-03$ & $2.54 \mathrm{E}-03$ & $2.51 \mathrm{E}-03$ & $2.58 \mathrm{E}-03$ & 4.18E-04 & $2.59 \mathrm{E}-03$ & $4.33 \mathrm{E}-04$ \\
\hline Thyroid & $2.84 \mathrm{E}-03$ & $1.70 \mathrm{E}-03$ & $1.98 \mathrm{E}-03$ & $2.20 \mathrm{E}-03$ & $2.04 \mathrm{E}-03$ & $2.15 \mathrm{E}-03$ & $4.25 \mathrm{E}-04$ & $2.14 \mathrm{E}-03$ & 4.09E-04 \\
\hline Adrenals & $2.49 \mathrm{E}-03$ & $1.24 \mathrm{E}-03$ & $1.79 \mathrm{E}-03$ & $1.64 \mathrm{E}-03$ & $1.89 \mathrm{E}-03$ & $1.81 \mathrm{E}-03$ & 4.54E-04 & $1.83 \mathrm{E}-03$ & $4.65 \mathrm{E}-04$ \\
\hline Muscle & $1.95 \mathrm{E}-03$ & $1.26 \mathrm{E}-03$ & $1.81 \mathrm{E}-03$ & $1.73 \mathrm{E}-03$ & $1.67 \mathrm{E}-03$ & $1.68 \mathrm{E}-03$ & $2.59 \mathrm{E}-04$ & $1.69 \mathrm{E}-03$ & 2.64E-04 \\
\hline Testes & $1.80 \mathrm{E}-03$ & $1.47 \mathrm{E}-03$ & $2.01 \mathrm{E}-03$ & $1.35 \mathrm{E}-03$ & $1.80 \mathrm{E}-03$ & $1.69 \mathrm{E}-03$ & $2.69 \mathrm{E}-04$ & $1.68 \mathrm{E}-03$ & $2.82 \mathrm{E}-04$ \\
\hline ULI wall & $2.03 \mathrm{E}-03$ & $1.22 \mathrm{E}-03$ & $1.62 \mathrm{E}-03$ & $1.58 \mathrm{E}-03$ & $1.63 \mathrm{E}-03$ & $1.62 \mathrm{E}-03$ & $2.87 \mathrm{E}-04$ & $1.62 \mathrm{E}-03$ & $2.91 \mathrm{E}-04$ \\
\hline Lungs & $1.21 \mathrm{E}-03$ & $1.19 \mathrm{E}-03$ & $1.62 \mathrm{E}-03$ & $1.45 \mathrm{E}-03$ & $1.65 \mathrm{E}-03$ & $1.42 \mathrm{E}-03$ & $2.18 \mathrm{E}-04$ & $1.57 \mathrm{E}-03$ & $2.69 \mathrm{E}-04$ \\
\hline Stomach & $1.29 \mathrm{E}-03$ & $7.16 \mathrm{E}-04$ & $1.03 \mathrm{E}-03$ & $9.61 \mathrm{E}-04$ & $1.05 \mathrm{E}-03$ & $1.01 \mathrm{E}-03$ & $2.06 \mathrm{E}-04$ & $1.03 \mathrm{E}-03$ & $2.15 \mathrm{E}-04$ \\
\hline LLI wall & $1.13 \mathrm{E}-03$ & 7.03E-04 & $9.55 \mathrm{E}-04$ & $9.38 \mathrm{E}-04$ & $9.32 \mathrm{E}-04$ & 9.32E-04 & $1.52 \mathrm{E}-04$ & $9.33 \mathrm{E}-04$ & $1.52 \mathrm{E}-04$ \\
\hline Effective dose equivalent & 4.53E- 03 & 2.63E-03 & 3.79E-03 & 3.02E-03 & $4.42 E-03$ & $3.68 E-03$ & $8.40 \mathrm{E}-04$ & $3.70 E-03$ & 8.69E-04 \\
\hline
\end{tabular}


adequately fitted by a decaying monoexponential. In the gall bladder, the small intestine, and the urinary bladder, the time-course was more protracted. Of the excreted ${ }^{11} \mathrm{C}$ activity at $1 \mathrm{~h}$, approximately $80 \%$ were eliminated via the hepato-biliary pathway and $20 \%$ through the urinary tract. The residence times are summarized in Table 1. Because of the large mass, it was largest in the muscles, followed by liver, bone marrow, and small intestine. The smallest values were found in the testes and the thyroid gland. The mean absorbed dose in the various organs is reported in Table 2. The highest absorbed dose was present in the liver, followed by gall bladder wall, kidneys, and small intestine. The agreement between the values calculated with the softwares Mirdose 3 and Olinda in the different organs was, in general, excellent. A small discrepancy was observed in the urinary bladder (Olinda, 17\% lower) and the lungs (Olinda, 10\% larger). Nevertheless, the mean effective dose equivalent was almost identical. The distribution of ${ }^{11} \mathrm{C}$ ABP688 in the brain is demonstrated in Fig. 3a. High tracer uptake is found in the cortex, especially in the mediotemporal area; less uptake was present in the thalamus, and the lowest tracer accumulation was present in the cerebellum. Corresponding tissue time-activity curves are illustrated in Fig. 3b.

a

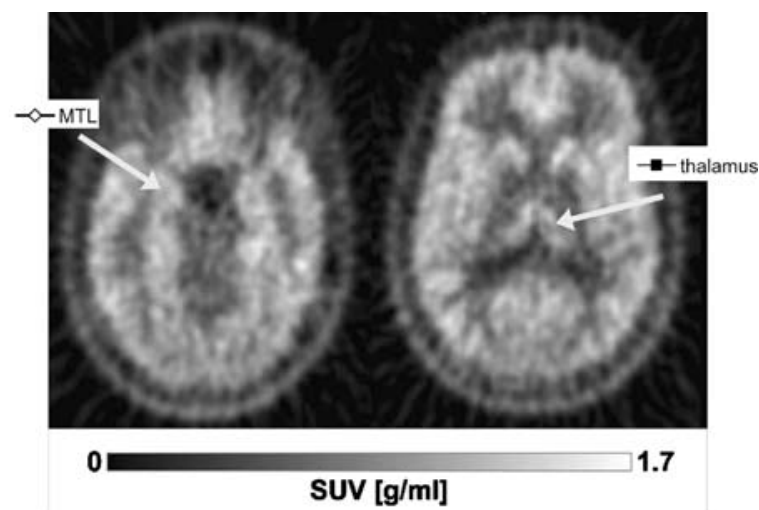

b

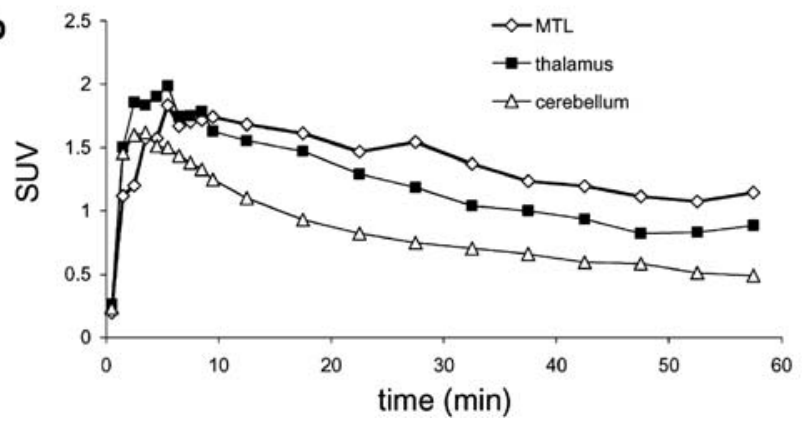

Fig. 3. ${ }^{11} \mathrm{C}-\mathrm{ABP} 688$ distribution in the brain $40-50 \mathrm{~min}$ after injections (a) and decay-corrected tissue time-activity curves of several brain areas (b). The data were taken from another study in which the brain distribution of ${ }^{11} \mathrm{C}$-ABP688 was evaluated [11]

\section{Discussion}

The presented data demonstrate a promising distribution and kinetics of ${ }^{11} \mathrm{C}$-ABP688 for the evaluation of mGluR5. Brain uptake is high, which results in high-quality images and good statistics for quantification. The pattern of tracer distribution in the brain is similar to the one described in our recent animal [8] and human study [11].

The study demonstrates that the main route of elimination of the tracer is the hepato-biliary pathway followed by the urinary tract. This is not surprising given the lipophilicity of ${ }^{11} \mathrm{C}-\mathrm{ABP} 688$. As a consequence, the liver and the gall bladder are the organs with the highest absorbed dose.

One possible error in the dosimetry could result from the monoexponential fitting, which was applied in this study. Especially in organs with a low retention of the tracer, there will be an early perfusion phase that is missed in wholebody scanning. To estimate this error, we assumed that this perfusion phase would add $20 \%$ to the residence times of myocardium, kidney, liver, lung, and bone marrow. The recalculation then revealed, that this $20 \%$ increase would add only $11 \%$ to the mean effective dose equivalent (4.10E$03 \pm 9.80 \mathrm{E}-04$ vs $3.70 \mathrm{E}-03 \pm 8.69 \mathrm{E}-04 \mathrm{mSv} / \mathrm{MBq}$ ).

Concerning radiation protection, ${ }^{11} \mathrm{C}-\mathrm{ABP} 688$ compares favorably with other receptor tracers. For example, the effective dose equivalent is lower than the 6.7 microSv/ $\mathrm{MBq}$ reported for ${ }^{11} \mathrm{C}$-raclopride, a marker to measure dopaminergic D2 receptors [12] and considerably lower than the 19 microSv/Mbq estimated for the tracer ${ }^{18} \mathrm{~F}$ Fluoro-A-85380, a candidate for the investigation of nicotinic receptors [13]. The injected amount of about $250 \mathrm{MBq}$ ${ }^{11} \mathrm{C}-\mathrm{ABP} 688$ resulted in an effective dose equivalent of $0.9-1.1 \mathrm{mSv}$. This low value allows multiple serial examinations of the same subject. For instance, an upper limit of the radiation burden of $5 \mathrm{mSv}$ would allow the injection of $1,000 \mathrm{Mbq}{ }^{11} \mathrm{C}$-ABP688, including the addition $11 \%$ increase caused by the possible underestimation because of monoexponential fitting. On modern scanners operated in 3D mode, $200 \mathrm{Mbq}$ are sufficient for a single scan, meaning that one subject could be investigated on five different occasions. This opens the possibility of very efficient interventional studies, for instance, receptor occupancy studies with new drugs aimed at interfering with the mGluR5 receptor.

Whole-body PET has been recently used for dosimetry studies in humans by several groups [12-16]. This became possible only recently with the latest generation of scanners that allow whole-body scanning with adequate temporal resolution. In the past, most dosimetry calculations were done with the software Mirdose3. Because of incompatibilities with newer operating systems, the code was rewritten and was made available as Olinda [10], which may become more widespread in the future. The excellent 
agreement of the values calculated with both programs indicates that they are interchangeable.

\section{Conclusion}

${ }^{11} \mathrm{C}$-ABP688 is a very promising ligand for the investigation of mGluR5 receptors in humans. Brain uptake is high and the effective dose equivalent so low that serial examinations in the same subject seem feasible.

Acknowledgment Valerie Treyer was supported by the Swiss National Science Foundation. The study was sponsored by Novartis, Basel, and supported by the 51NF40-111381 (NCCR Neuro) and EU LSHM-CT-2003-503330 (APOPIS). We thank Esmeralda Gruber for the excellent clinical study support.

\section{References}

1. Masu M, Tanabe Y, Tsuchida K, Shigemoto R, Nakanishi S. Sequence and expression of a metabotropic glutamate receptor. Nature 1991;349(6312):760-5.

2. Gasparini F, Lingenhohl K, Stoehr N, Flor PJ, Heinrich M, Vranesic I, et al. 2-Methyl-6-(phenylethynyl)-pyridine (MPEP), a potent, selective and systemically active mGlu5 receptor antagonist. Neuropharmacology 1999;38(10):1493-503.

3. Kuhn R, Pagano A, Stoehr N, Vranesic I, Flor PJ, Lingenhohl K, et al. In vitro and in vivo characterization of MPEP, an allosteric modulator of the metabotropic glutamate receptor subtype 5: review article. Amino Acids 2002;23(1-3):207-11.

4. Spooren W, Gasparini F. mGlu5 receptor antagonists: a novel class of anxiolytics? Drug News Perspect 2004;17:251-7.

5. Spooren WP, Vassout A, Neijt HC, Kuhn R, Gasparini F, Roux S, et al. Anxiolytic-like effects of the prototypical metabotropic glutamate receptor 5 antagonist 2-methyl-6-(phenylethynyl)pyridine in rodents. J Pharmacol Exp Ther 2000;295(3):1267-75.

6. Tatarczynska E, Klodzinska A, Chojnacka-Wojcik E, Palucha A, Gasparini F, Kuhn R, et al. Potential anxiolytic- and antidepres- sant-like effects of MPEP, a potent, selective and systemically active mGlu5 receptor antagonist. Br J Pharmacol 2001;132 (7):1423-30.

7. Hamill TG, Krause S, Ryan C, Bonnefous C, Govek S, Seiders TJ, et al. Synthesis, characterization, and first successful monkey imaging studies of metabotropic glutamate receptor subtype 5 (mGluR5) PET radiotracers. Synapse 2005;56(4):205-16.

8. Ametamey SM, Kessler LJ, Honer M, Wyss MT, Hintermann S, Auberson YP, et al. Radiosynthesis and preclinical evaluation of $[11 \mathrm{C}]-\mathrm{ABP} 688$ as a probe for imaging the metabotropic glutamate receptor subtype 5 (mGluR5). J Nucl Med 2005; 47:698-705.

9. Stabin MG. Mirdose: personal computer software for internal dose assessment in nuclear medicine. J Nucl Med 1996;37(3):538-46.

10. Stabin MG, Sparks RB, Crowe E. Olinda/EXM: the secondgeneration personal computer software for internal dose assessment in nuclear medicine. $\mathrm{J}$ Nucl Med 2005;46 (6):1023-7.

11. Ametamey SM, Treyer V, Streffer J, Wyss MT, Schmidt M, Blagoev M, et al. Human PET studies of metabotropic glutamate receptor subtype 5 with 11C-ABP688. J Nucl Med 2007;48 (2):247-52.

12. Ribeiro MJ, Ricard M, Bourgeois S, Lievre MA, Bottlaender M, Gervais $\mathrm{P}$, et al. Biodistribution and radiation dosimetry of [11C] raclopride in healthy volunteers. Eur J Nucl Med Mol Imaging 2005;32(8):952-8.

13. Bottlaender M, Valette H, Roumenov D, Dolle F, Coulon C, Ottaviani $\mathrm{M}$, et al. Biodistribution and radiation dosimetry of $18 \mathrm{~F}$ fluoro-A-85380 in healthy volunteers. J Nucl Med 2003;44 (4):596-601.

14. Obrzut SL, Koren AO, Mandelkern MA, Brody AL, Hoh CK, London ED. Whole-body radiation dosimetry of 2-[18F]Fluoro-A85380 in human PET imaging studies. Nucl Med Biol 2005;32 (8):869-74.

15. Seneca N, Andree B, Sjoholm N, Schou M, Pauli S, Mozley PD, et al. Whole-body biodistribution, radiation dosimetry estimates for the PET norepinephrine transporter probe $(\mathrm{S}, \mathrm{S})-[18 \mathrm{~F}]$ FMeNER-D2 in non-human primates. Nucl Med Commun 2005; 26(8):695-700.

16. Slifstein M, Hwang DR, Martinez D, Ekelund J, Huang Y, Hackett E, et al. Biodistribution and Radiation dosimetry of the dopamine D2 Ligand 11C-raclopride determined from human whole-body PET. J Nucl Med 2006;47(2):313-9. 